\title{
The Book of Job and the Role of Uncertainty in Religion and Law
}

Steven Goldberg

Georgetown University Law Center, goldberg@law.georgetown.edu

Inaugural Address as James and Catherine Denny Professor of Law, Georgetown University Law Center, Washington, DC, February 26, 2009

This paper can be downloaded free of charge from:

http://scholarship.law.georgetown.edu/fac_lectures/8 


\title{
GEORGETOWN LAW Faculty Lectures
}

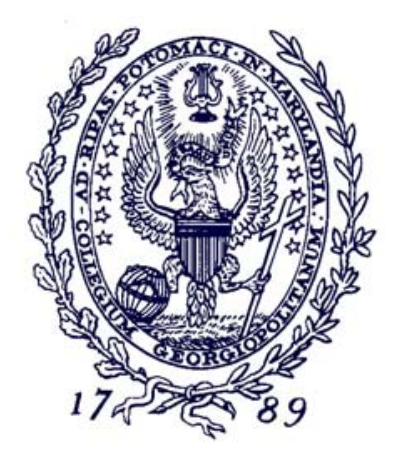

Georgetown Public Law and Legal Theory Research Paper No. 09-11 September 2010

\section{The Book of Job and the Role of Uncertainty in Religion and Law}

\author{
Inaugural Address as James and Catherine Denny Professor of Law \\ Georgetown University Law Center, Washington, DC, February 26, 2009
}

\section{Steven Goldberg}

\author{
Professor of Law
}

Georgetown University Law Center

goldberg@law.georgetown.edu

This paper can be downloaded without charge from:

Scholarly Commons: http://scholarship.law.georgetown.edu/fac lectures/8/

SSRN: http://ssrn.com/abstract $=1410683$

Posted with permission of the author 
The Book of Job and the Role of Uncertainty in Religion and Law

\author{
Steven Goldberg \\ Georgetown University Law Center
}

Inaugural Address as James and Catherine Denny Professor of Law, Georgetown University Law Center, Washington, DC, February 26, 2009.

Thank you Dean Aleinikoff and Professor Jackson, and, most of all, thank you James and Catherine Denny, for your extraordinary generosity. I'd like to thank everyone for coming today. I'm particularly delighted that my son Joe and my daughter Becky could be here, as well as my wife, Missy. Just yesterday, someone asked me the secret of a happy marriage, and I told him it was easy: Marry Missy.

Before I turn to the Book of Job, I want to say just a few words about how strongly I feel about Georgetown Law. You know, I've read a few autobiographies over the years of prominent federal officials who came to Washington, and they often begin in the same dismaying way. They start by saying, "Washington was a sleepy Southern town before I arrived." And I'm afraid some professors sometimes talk that way about their universities: "Well, this really wasn't a very scholarly place before I got here"

That is, most emphatically, not my view of Georgetown Law. When I joined the faculty in 1977, this law school had already been around for over a hundred years and it was already a terrific place. It had famous graduates much in the news such as John Sirica and Edward Bennett Williams, and it had a remarkable dean in Dave McCarthy. Georgetown Law has gotten even better over the ensuing decades, and I've just been delighted to be along for the ride. And that leads me to the most important thing I want to say today: I owe more to Georgetown Law than Georgetown Law owes to me, and I hope I never forget that.

Let me turn now to the Book of Job and the Role of Uncertainty in Religion and Law. I'd like to present the ideas I've been developing, and then take any questions and comments that you might have.

Written more than 2,500 years ago, the Book of Job has had enormous influence on religion, philosophy and literature because of its 
uncompromising story of a blameless man who suffers at God's hand for reasons no ordinary mortal can understand.

One reason for the enduring appeal of the Book is its universal nature. Job himself is never identified as a member of any religion or tribe or national group. He is a person who suffers, who never understands why, and yet never loses his faith. The Book itself appears in the Hebrew Bible, and thus, is, of course, central in Judaism. But Job is also referenced numerous times in the New Testament, particularly in the Book of Romans and in Corinthians. And Job is discussed in the Koran as well, where we learn that inspiration was sent to "Abraham, Isaac, Jacob, Jesus, and Job.”

Let me just briefly retell the story as it appears in the Bible. Job was a prosperous and pious man who was married with many children. God, while talking with a heavenly figure, called "the adversary" in the Jewish translation and "Satan" in the King James version, notes how truly God fearing Job is. But the adversary says Job is pious only because he is successful. So God gives Satan permission to destroy Job's possessions, to kill his children, and ultimately to afflict Job himself with dreadful boils. Throughout all of these tragedies, Job refuses to curse God, saying "the Lord giveth and the Lord taketh away, blessed be the name of the Lord" and saying as well, "Shall we accept good from God and not accept adversity?"

While Job is suffering he is visited by three friends, Eliphaz, Bildad, and Zophar. (A fourth, Elihu, is likely a later addition to the text.) They all tell Job that God rewards the just and punishes the wicked. Therefore Job, whether he realizes it or not, must have done something wrong, and he should repent. Now in modern parlance we often speak of "the patience of Job.” But, in fact, Job is notably confrontational, angry and impatient with these three friends. He sharply denies that he did anything wrong, he laments that he is suffering, and he demands to know why he is being treated so badly.

Finally, God speaks to Job "out of the whirlwind” and says:

"Who is this who darkens counsel with words without knowledge? Now prepare yourself like a man. I shall question you and you shall answer me. Where were you when I laid the foundations of the earth?”

And then God continues with scores of questions, "Have you 
commanded the mornings since your days began? .... Have you seen the doors of the shadow of death?” and so on. No answers of any kind are give to Job. Faced by this barrage, Job finally surrenders, "I have uttered what I did not understand," he says and he repents. God then restores Job's riches and his family. While doing this, God utters the statement that is perhaps the most crucial part of the entire Book: he condemns Job's three friends, saying "my wrath is aroused against you, because you have not spoken of Me what is right, as my servant Job has.”

The message appears to be that any effort by humans to understand God is hopeless. Even the usual rationalizations of Job's friends - God rewards good and punishes evil; God surely has a plan - even those are too bound by human limitations to begin to explain the ways of the Lord.

So the Book of Job confronts us not only with the famous question of the origin of evil - why do bad things happen to good people - it confronts the broader, even more unsettling possibility that there are countless crucial things about life and the universe that we can never comprehend.

Needless to say, Job has been a continuing source of study and commentary within religious communities. It is discussed in the Jewish Talmud, and by Jewish commentators throughout the years. Maimonides, for example, wrote in the $12^{\text {th }}$ Century that while Job is described as a good man and a faithful man, we are never told that he was a learned man. So perhaps he was punished because he hadn't studied enough. (Maybe I should make that point to my students from time to time.)

The Book of Job has also occasioned a good deal of commentary in the Christian tradition. G.K. Chesterton, for example, in a famous essay, praises the Book because in it God routs the human skeptics by propounding a higher skepticism. Chesterton suggests that Job's wounds prefigure those of Jesus and lead us toward the new hope that Jesus provides.

Job's influence in modern, secular philosophy is also substantial. Most obviously existentialism is shaped by a Jobian view of the inevitable collision when humans confront a remorseless, irrational universe. The references to Job are explicit in Kierkegaard and very close to the surface in Camus. Moving further into modern philosophy, some scholars have seen traces of Job in Wittgenstein's insistence that we must recognize the enormity of what we cannot know and cannot speak of. And just this year, 
the American philosopher Susan Neiman, in her book Moral Clarity, analyzes the Book of Job in an effort to plumb the religious and secular bases of morality.

Job's influence in literature has been equally great. From Moby Dick to Kafka's Trial, Job looms large. And the story of Job has been explicitly retold in modern dress by many authors, perhaps most effectively in Archibald MacLeish's 1958 play JB, which won the Pulitzer Prize, and which has been staged again and again, right down to the present day.

For my money, the literary passage that best captures the fundamental idea in Job appears in Graham Greene's novel Brighton Rock. At the end of the book, a young widow confesses to a Catholic priest that her husband, a violent criminal, has committed suicide, and she wonders if damnation is inevitable. The old priest sighs and says "you can't conceive, my child, nor can I or anyone - the appalling strangeness of the mercy of God.”

"The appalling strangeness of the mercy of God.” That captures one of the most difficult and unsettling things we learn in life. Not only is evil sometimes inexplicable, but good fortune and mercy can be just as mysterious as well.

What happens when we turn our attention to the law? Here we find what is to me an astonishing result: there is virtually no engagement with the Book of Job. Judges don't cite it, lawyers don't talk about it, even law professors rarely mention it in their writings or lectures. Of course, in the natural law tradition, in which law is a branch of theology or philosophy, you will find discussions of Job -- usually what you'll find is efforts to explain it away. But modern American law does not explicitly use natural law discourse, and it is remarkable the extent to which Job is neither praised nor criticized; it is simply ignored.

Consider judicial opinions. A Lexis search of all federal and state courts reveals that the Book of Job was cited only a handful of times in the last fifty years. Now you might say, well, how often does a Court cite any Biblical or literary source? The answer is actually quite a bit. You will find more references to the Book of Matthew -- "blessed are the peacemakers" for example, than to Job. But if you really want to see an influential literary source for judicial thinking I would recommend Alice in Wonderland. There are literally more than one hundred citations to Alice in Wonderland for 
every one to Job. Judges love to go through the Looking Glass. And don't suppose that they are always using Alice to criticize what a party is saying. Just a couple of years ago, Justice Souter, wrote for the Court in a criminal case [Lopez v. Gonzales]: "We cannot forget that we ultimately are determining the meaning of the term "crime of violence". Which is not to deny that the Government might still be right: Humpty Dumpty used a word to mean "just what he chose it to mean - neither more nor less", and legislatures, too, are free to be unorthodox. Congress can define an aggravated felony of illicit trafficking in an unexpected way.”

Souter enjoyed writing this. Judges and lawyers love to play with ambiguous words, and so they love to cite Lewis Carroll. And, by the way, I've read those very few cases in which Job is cited, and I can tell you one thing: if the Judge compares your client to Job you are in major trouble! Consider the Pennsylvania case [Yandrich v. Radic, 1979] in which the opinion begins: "The background of this case reads like a page from the Book of Job. Five children were born to George and Bertha Yandrich. The first three, at the ages of three, two and eight months perished tragically when their father's runaway car sank in a dam.... the fourth child, George, was fatally injured in an automobile accident [in which the driver was negligent.]" The Court continued by explaining that, learning of the accident, George committed suicide, and this led to this lawsuit for the negligent infliction of emotional distress. But, the Court concluded, the plaintiff's complaint fails under Pennsylvania precedent. It is almost as though the Judge enjoyed playing the part of God.

But the big point is that judges almost never mention Job. The reason is that if you think about how lawyers and judges talk about the law, you quickly run into a paradox. On the one hand, you could say that in the law everything seems saturated with uncertainty. Very few legal matters of any complexity are as simple or as clear cut as 2 plus 2 equals 4 . Lawyers love to say that virtually any case is winnable and virtually any case is losable. Ambiguities of doctrine, disputes over facts, changing social norms, the judge's political leanings, and many other factors can shape the outcome of a dispute. But this proves too much. For what happens in ordinary legal discourse is that an awful lot simply gets converted into odds.

Suppose a drug company executive is considering a certain course of action in response to a regulator's request for documents, and he asks his lawyer if the government could force wider disclosure in a lawsuit. The 
lawyer might say something like, "your approach is quite likely to be upheld in Court." If pressed she might even say, "I'd put the odds in your favor at something like ten to one." Of course, on other facts the odds might be very different.

This is uncertainty, but of a very mundane and manageable sort. It is nothing like the radical lack of knowledge that Job must live with after God speaks out of the whirlwind. To say that the law is uncertain is like saying that we don't know who will win the Academy Award for Best Actor. We play the odds, and eventually we will have a result of some sort.

Thus the uncertainty we are quite happy to live with as lawyers is of a very uniform kind. We see it, to a greater or lesser extent, wherever we look in our professional lives. We deal with it, and life goes on. There is nothing like the abyss Job peers into.

The lack of engagement with the unknown is even more dramatic when we look at judicial decisions. Of course, every Judge understands at some level that certain cases might be awfully hard to decide correctly: that the best outcome might shrouded in mystery. But the Judge understands as well that not to decide is a decision. There is nowhere to hide. You cannot indulge a taste for the unknown.

Suppose, for example, that a Congressional statute regulating pornography on the Internet takes effect, and is then challenged in federal district court on First Amendment grounds. If the judge literally does nothing - paralyzed perhaps by the great uncertainties involved - the statute remains in effect, and the cost to the First Amendment is ignored. One side has lost and the other has won. You have made a decision. So whether she likes it or not, the judge has to plunge into all of the uncertainties, all the odds, and render a decision. One result of all this may be that judges, in order to increase the social acceptability of their decisions, write opinions that ring of certainty, making the law seem more clear than it is.

Now, again, you might say that I am mixing categories: law is a profession, not a philosophical stance toward the universe, so we shouldn't expect to see open admissions about deep uncertainty. But that lets us off too easily. Consider, for example, another professional group - scientists.

Every great scientist has a sharp sense of what he does not know. 
Often there is a faith that ultimately matters will become clear, but just as often there is a sense that, as humans, we may never reach the end of our inquiries. Isaac Newton wrote:

I do not know what I may appear to the world, but to myself I seem to have been only like a boy playing on the sea-shore, and diverting myself in now and then finding a smoother pebble or a prettier shell than ordinary, whilst the great ocean of truth lay all undiscovered before me.

And these kinds of reflections apply not just to cutting-edge physics. Even a humble area like turbulence, which describes the flow of water through a pipe, is, in practice, so complex that our equations do not fully describe it. That's one reason we don't know which pipe will break in the winter and when it will happen. On his death bed, Werner Heisenberg is reported to have said, "When I meet God, I am going to ask him two questions: Why relativity? And why turbulence? I really believe he will have an answer for the first."

My choice of great scientists like Newton and Heisenberg is not random. Observers have long noted that the greater the scientist, the greater his sense of how little he knows.

For a judge, a deep sense of the difficulties of your task, a sense that the unknowable shapes your work, is the mark not of greatness but of mediocrity. Consider Supreme Court Justice Charles Evans Whittaker. He did not lack credentials or legal ability before becoming a Justice. Indeed he had served on a federal district court and a federal court of appeals before joining the High Court in 1957. As a Justice he worked longer hours than any of his colleagues as he struggled to make his way through the cases, unable in most instances to see a clear legal path to a correct answer. Lists of the least effective Justices in history invariably include Whittaker, who was so paralyzed by indecision that he literally could not cast a vote in the pivotal case of Baker v. Carr, and who resigned in 1962 after suffering a nervous breakdown.

Most judges learn to put uncertainties aside, to march through every case, hard or easy, and to take on the professional persona of the law: a persona that abhors the truly unknown. 
In sum, scientists, like many philosophers, have a sense of the difference between the known and the unknown. Maybe the known is not fully understood, maybe we have glimpses of the unknown, but there is a boundary, a border, and we feel some sense of awe and humility when we gaze across it.

The law is more uniform. It is like an unbounded field, rocky in some places, smooth in others, but essentially unmysterious. The law is a source of analysis and probing and odds making, not a source of wonder.

This may not be a problem to be solved. Perhaps it is inevitable. But we might want to consider some of the personal costs to the legal profession. If we do not leaven the day-to-day perspective of the lawyer with other sources of values, we may end up paying a price. A typical stance of the lawyer toward uncertainty and surprise is not one of awe, but rather one of cynicism: A lawyer who loses a case might say, "Well, of course, the judge ignored the statute: he used to work for the oil industry."

And the characteristic stance of the lawyer toward the legal world is not the humility of a Newton, but the arrogance of a gun fighter. I have trouble imaging a lawyer saying, "I am like a boy playing on the sea-shore whilst the great ocean of truth lay all undiscovered before me.” A lawyer is more likely to say, "I own that jury!"

Before I take your questions and comments, let me just conclude by saying that I believe, as people, we would be wise to combine legal learning and teaching with humility and care, indeed with the insights from the moral teachings of many disciplines. I am extremely grateful that Georgetown Law has given me a place to think about these kinds of things, and of that I am certain. Thank you. 